\title{
KONFLIK AGRARIA DAN PELEPASAN TANAH ULAYAT (STUDI KASUS PADA MASYARAKAT SUKU MELAYU DI KESATUAN PEMANGKUAN HUTAN DHARMASRAYA, SUMATERA BARAT) (Agrarian Conflict and Communal Land Release: A Case Study of M elayu Tribe in Forest Management Unit D harmasraya, West Sumatra)
}

\author{
Abdul Mutolib ${ }^{1}$, Yonariza ${ }^{2}$, Mahdi' ${ }^{2}$, Hanung Ismono ${ }^{3}$ \\ ${ }^{1}$ Program Studi Ilmu-Ilmu Pertanian, Pascasarjana Universitas Andalas \\ Jl. Limau Manis, Kecamatan Pauh, Padang, Sumatera Barat 25163, Indonesia \\ e-mail: amutolib24@yahoo.com \\ ${ }^{2}$ Program Studi Agribisnis, Fakultas Pertanian, Universitas Andalas \\ Jl. Limau Manis, Kecamatan Pauh, Padang, Sumatera Barat 25163, Indonesia \\ ${ }^{3}$ Program Studi Agribisnis, Fakultas Pertanian, Universitas Lampung \\ Jl. Prof. Dr. Soemantri Brojonegoro No.1 Bandar Lampung, 35145, Indonesia
}

Diterima 6 Mei 2015, direvisi 28 O ktober 2015, disetujui 2 November 2015

\begin{abstract}
ABST RACT

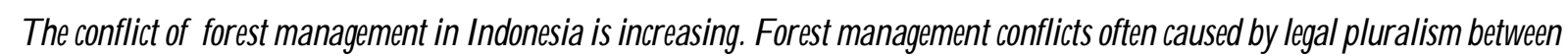

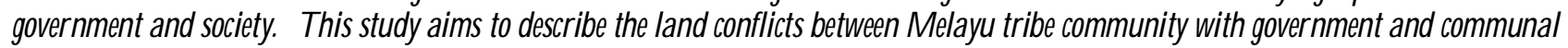
land reeseprocess in Mdayu tribein Dhamasraya Production Forest Managment Unit (PFMU). Resernch mothod was using descriptivequalitative Thestudywas conductedinPFMU inNagari Banjd, KotoBesar Dhamasraya Regengy. Theresults showed that 1) Agraian conflict in PFMU Dhammasraya between commmity and the guemment ocared due to the reegnition of leegl puralismin theforest, and2) Commmal landrdeaseocuredthroughtheprocess of buyingandsellingwhicharecontrdledbyDatuak astomaryauthorities Evideneof tradingadivitiesarecontrdledbytheissuanceof "alashak" asasignthat thecommmal landhas beensdd Theincrease of tradingadivities of communal landwereduetolowprices of commmal landand thehighpulicinterest to plantin commmal landonnedbyMdayutribe Somestrateejesarerequiredtomaintainthefunction of forestsinPFMU that hasbeen acquireelbylocal community withattnejetingloal commuitieswhodppendanforests.
\end{abstract}

Keguards: Agraianconflids, legal pluralismalashak, commmal land, PFMU

\begin{abstract}
ABSTRAK
Konflik pengelolaan hutan di Indonesia semakin meningkat jumlahnya. Konflik pengelolaan hutan seringkali disebabkan karena adanya pluralisme hukum antara pemerintah dan masyarakat. Tujuan penelitian ini adalah mendeskripsikan konflik lahan yang terjadi antara masyarakat adat Suku Melayu dengan pemerintah dan proses terjadinya pelepasan tanah ulayat Suku Melayu di Kesatuan Pemangku Hutan Produksi (KPHP) Model D harmasraya. D esain penelitiannya adalah deskriptif kualitatif dengan lokasi penelitian di KPHP yang berada di Nagari Bonjol, Kecamatan Koto Besar, Kabupaten D harmasraya. Hasil penelitian menunjukkan bahwa 1) Konflik agraria yang terjadi di KPHP antara masyarakat adat dengan pemerintah dikarenakan adanya legal pluralism dalam pengakuan hutan, dan 2) Proses pelepasan tanah ulayat terjadi melalui transaksi jual beli yang dikendalikan oleh Datuak penguasa ulayat. Bukti kegiatan jual beli adalah dikeluarkannya "alashak" sebagai bukti bahwa tanah ulayat telah dijual. Maraknya kegiatan jual beli tanah ulayat disebabkan harga tanah ulayat yang rendah dan tingginya minat masyarakat berkebun di tanah ulayat Suku Melayu. Diperlukan strategi yang tepat untuk mempertahankan fungsi kawasan hutan di wilayah K PHP tanpa mengabaikan keberadaan masyarakat lokal yang menggantungkan hidupnya dari hutan.
\end{abstract}

Kata kunci: Konflik agraria, pluralisme hukum, alashak, tanah ulayat, KPHP 


\section{PENDAHULUAN}

Di era reformasi konflik agraria di Indonesia semakin meningkat jumlahnya (Astuti, 2011). Menurut Badan Pertanahan Nasional, pada tahun 2011 telah terdaftar sekitar 3.500 konflik lahan yang didominasi sengketa masyarakat dengan perusahaan kelapa sawit (Colchester dan Chao, 2011). Secara umum konflik agraria di Indonesia terjadi antara masyarakat dengan perusahaan pemegang izin lahan (Astuti, 2011). Konflik agraria terjadi karena terjadinya tumpang tindih penggunaan lahan antara masyarakat dan pemerintah/ perusahaan (Mantiri, 2007).

Di beberapa lokasi, tumpang tindih penguasaan tanah di Indonesia terjadi karena adanya leegl puralism(Larson, 2012 ). Legal pruralismmerupakan situasi di mana dua atau lebih sistem hukum berinteraksi dalam satu kehidupan sosial (Hooker,1975). Karena adanya dua hukum yang berbeda masyarakat dan pemerintah terjadi saling klaim hak atas tanah/ hutan. Masing-masing pihak hanya mengakui keberadaan satu hukum demi kepentingannya (von Benda-Beckmann, 1981).

Di Indonesia hukum negara dianggap memiliki posisi yang lebih tinggi dalam pengelolaan sumberdaya alam dibandingkan hukum adat (Larson, 2012). Seringkali negara mengambil kebijakan sepihak dalam pengelolaan sumber daya alam tanpa melibatkan masyarakat lokal yang menggantungkan hidup pada sumber daya alam tersebut. Pada saat ini terjadi 'dualismeyangmandul' (Onibon \&al, 1999) yaitu negara memberlakukan peraturan perundang-undangan yang dipastikan tidak dapat dijalankan dan tidak selaras dengan penerapan lokal, akibatnya aturan tersebut pasti diabaikan namun tindakan penduduk setempat dipidanakan (Benjamin, 2008).

Kasus tumpang tindih kepemilikan hutan akibat pluralisme hukum terjadi di Kesatuan Pengelolaan Hutan Produksi (KPHP) Model Dharmasraya Provinsi Sumatera Barat. Secara hukum negara, wilayah tersebut merupakan Hutan Tanaman Industri (HTI) yang izinnya diberikan kepada pihak ketiga. Tetapi secara hukum adat tanah tersebut merupakan tanah ulayat Suku Melayu yang telah ditempati sejak ratusan tahun. Akibatnya terjadilah konflik agraria dikawasan K PHP antara masyarakat dan negara/ perusahaan pemegang izin (Mutolib \& al, 2015). D alam hal ini, negara tidak mengakui keberadaan hukum adat sehingga keberadaan hukum adat dalam posisi yang lemah (G riffiths, 1986).

Konflik agraria di KPHP terjadi sejak awal tahun 2000. Konflik terjadi di areal hutan seluas 33.550 ha bekas HPH Ragusa yang dijadikan HTI milik PT. Inhutani dan PT. D hara Silva (PT. DS) (Dinas Kehutanan Kabupaten Dharmasraya, 2014). Konflik yang terjadi merupakan konflik perebutan lahan perusahaan oleh masyarakat (Mutolib \& al., 2015). Hingga saat ini, lahan Inhutani dan D Syang kini menjadi KPHP sebagian besar telah dikuasai oleh masyarakat lokal dan diubah menjadi perkebunan karet dan kelapa sawit (Yonariza, 2015). Setelah berhasil merebut hutan, terjadi transaksi tanah di areal konflik yakni kegiatan pelepasan atau jual beli tanah ulayat ke masyarakat luar Suku Melayu (Mutolib \&al., 2015). Pelepasan tanah ulayat Suku Melayu terjadi dalam skala masif dan terus menerus (Mutolib eal,2015). Akibat kegiatan jual beli tanah tanah ulayat, masyarakat Suku Melayu terancam kehilangan tanah ulayatnya.

Berdasarkan uraian tersebut dan latar belakang masalah yang telah dikemukakan sebelumnya, maka pokok masalah dalam penelitian ini adalah konflik agraria dan pelepasan tanah ulayat yang dituangkan ke dalam bentuk pertanyaan penelitian, sebagai berikut:

1. Bagaimana asal mula konflik lahan yang terjadi antara masyarakat lokal dan negara/ pemegang izin di areal K PHP Model D harmasraya?

2. Bagaimana proses pelepasan tanah ulayat Suku Melayu di areal KPHP Model D harmasraya?

Adapun tujuan penelitian ini adalah untuk memberikan deskripsi tentang konflik lahan yang terjadi antara masyarakat adat Suku Melayu dengan pemerintah/ pemegang izin, serta proses pelepasan tanah ulayat Suku Melayu kepada masyarakat non Suku Melayu atau masyarakat luar Kabupaten Dharmasraya. Hasil penelitian ini diharapkan menjadi bahan pertimbangan bagi pengelola untuk meningkatkan intensitas pengelolaan dan monitoring di KPHP untuk memcegah pembukaan hutan secara terus-menerus yang pada akhirnya menyebabkan deforestasi dan alih fungsi hutan. 


\section{METODE PENELITIAN}

\section{A. Lokasi dan Waktu Penelitian}

Penelitian dilaksanakan di Nagari Bonjol Kecamatan Koto Besar Kabupaten D harmasraya. Lokasi dipilih secara sengaja, karena secara hukum adat, areal KPHP D harmasraya merupakan tanah ulayat Suku Melayu Nagari Bonjol yang telah ditempati sejak ratusan tahun yang lalu. Lama waktu penelitian selama dua bulan, mulai bulan Februari hingga Maret 2015.

\section{B. Pengumpulan Data dan Pengambilan Sampel}

Metode penelitian menggunakan metode studi kasus dengan berbagai teknik pengumpulan data seperti observasi, penelusuran sejarah, wawancara key informant, dan dilengkapi dengan survei rumah tangga (Faisal, 1990).

Survei rumah tangga dilakukan untuk mengetahui karakteristik masyarakat, penguasaan lahan, persepsi terhadap leegl pluralism dan pengelolaan hutan oleh pemerintah/ pemegang izin. Sampel rumah tangga sebanyak 41 dari 512 rumah tangga petani menggunakan rumus Slovin (1988) dalam Djari (2009). Pengambilan sampel rumah tangga menggunakan metode sampingacidential (Sugiyono, 2013). Metode sampling accidential sengaja dipilih karena sulitnya menemui masyarakat, masyarakat hanya berada di rumah antara sore hingga malam, sisanya dihabiskan di kebun. Bahkan beberapa petani bermalam dikebun hingga bermingguminggu lamanya.

Key informant melibatkan 17 orang terdiri dari tokoh adat (Ninik mamak dan Datuak penguasa ulayat), perangkat nagari, ketua lembaga masyarakat, pemegang izin hutan, dan perwakilan dinas terkait. Penentuan kejinformantmenggunakan metode snorball sampling(Sugiyono, 2013).

Pengumpulan data dilakukan dengan mengutamakan pandangan informan dan peneliti sendiri memerankan diri sebagai instrumen utama (key instrument) yang terjun langsung ke lapangan untuk melakukan pengumpulan data secara mendalam. Hal ini sesuai dengan pendapat Bogdan dan Biklen (1992) bahwa: "Qualitativerearchhasthe natural settingas thesarce of data and rearcher is key instrument".

\section{Rancangan Penelitian dan Analisis Data}

Penelitian ini menggunakan pendekatan kualitatif. Strauss dan Corbin (2013) mendefinisikan penelitian kualitatif sebagai metode penelitian yang temuan-temuannya tidak diperoleh melalui prosedur statistik atau bentuk hitungan lainnya. Afrizal (2015) menjelaskan bahwa penelitian kualitatif merupakan penelitian yang sumber datanya berupa kata-kata dan perbuatan manusia atau kelompok yang menggunakan metode observasi, wawancara mendalam dan pengumpulan dokumen. Penelitian kualitatif bertujuan untuk membuat deskripsi, gambaran atau lukisan secara sistematik, faktual dan akurat mengenai faktafakta, sifat-sifat serta hubungan antar fenomena yang diamati (Moleong, 1996).

Analisis data menggunakan analisis kualitatif (Bungin, 2010). Secara operasional analisis data penelitian kualitatif adalah proses menyusun data (menggolongkannya dalam tema atau kategori) agar dapat ditafsirkan atau diinterpretasikan. Analisis data dalam penelitian kualitatif dilakukan sejak sebelum memasuki lapangan, selama di lapangan dan setelah selesai di lapangan (Sugiyono, 2013; Afrizal, 2015). Pada prinsipnya analisis ini dilakukan setiap saat selama penelitian berlangsung. Kegiatan pengumpulan dan analisis data dalam penelitian ini tidak terpisah satu sama lain. Keduanya berlangsung secara simultan dan prosesnya berbentuk siklus (Creswell, 1994). O leh karenaitu, penelitian ini menggunakan analisis data model interaktif melalui tiga alur kegiatan, yaitu: 1) reduksi data, 2) display data, dan 3) penarikan kesimpulan/ verifikasi (Miles dan Huberman, 1992), seperti pada Gambar 1. 


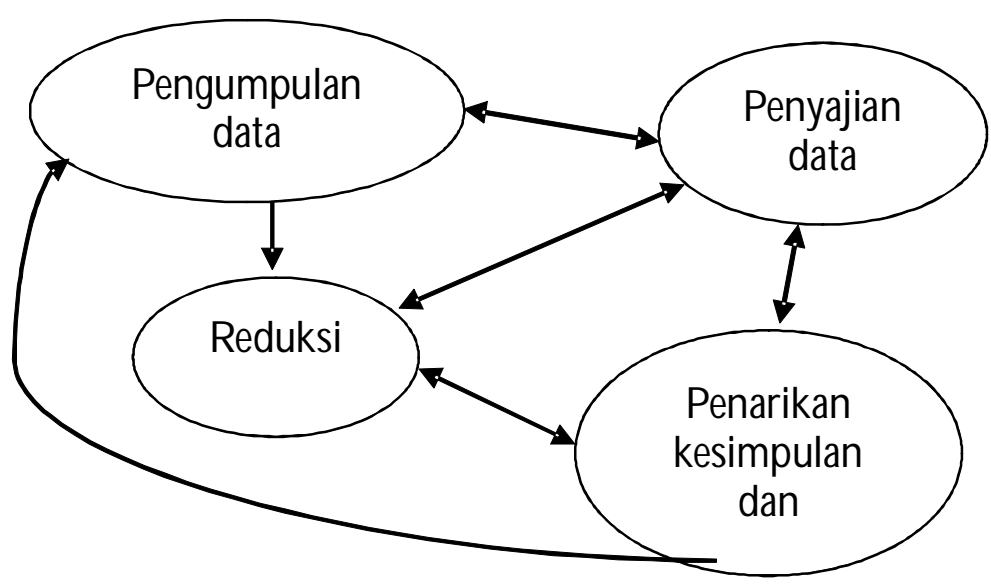

Sumber (Sarce): Miles dan Huberman (1992)

G ambar 1. Analisis data dan model interaktif.

Figre1. Data analysisandinteradivemodd.

\section{HASIL DAN PEMBAHASAN}

\section{A. Gambaran Umum Lokasi penelitian}

Lokasi penelitian berada di KPHP D harmasraya yang berada di Kabupaten D hamasraya Provinsi Sumatera Barat. KPHP memiliki luas wilayah sekitar 33.550 ha (Dinas Kehutanan Kabupaten D harmasraya, 2014). Secara hukum adat wilayah K PHP berada di tanah ulayat Suku Melayu Nagari Bonjol.

Nagari Bonjol secara administrasi masuk kedalam wilayah Kecamatan Koto Besar, Kabupaten D harmasraya Provinsi Sumatera Barat. Nagari Bonjol merupakan nagari terluas di Kecamatan Koto Besar dibandingkan enam Nagari lainnya. Luas Nagari Bonjol adalah 268,83 km² atau 55,07\% dari total luas Kecamatan Koto besar 488,19 km² (Badan Pusat Statistik Dharmasraya, 2014). Sebagian besar masyarakat Bonjol bekerja sebagai petani dengan komoditas utama tanaman karet dan kelapa sawit, dan sebagian wilayahnya berada di KPHP.

Nagari Bonjol merupakan Nagari yang masih menjunjung tinggi adat istiadat dalam kehidupan bermasyarakat. Hampir semua aktivitas masyarakat diatur oleh adat. Untuk mengatur kehidupan masyarakat maka dibentuklah "Ninik Mamak" di Nagari Bonjol. Ninik Mamak/ Datuk adalah seorang pemimpin informal/ pemuka adat di Minangkabau yang memilikiperanan yang cukup besar di bidang ekonomi, pendidikan dan sosial budaya, baik dilingkungan persukuannya selaku kepala suku maupun dilingkungan nagarinya yang diwadahi didalam lembaga KerapatanAdat Nagari (KAN) (Indrawardi, 2008).

Di Nagari Bonjol terdiri dari lima suku. Sukusuku di Nagari Bonjol dipimpin oleh seorang Datuak yang merangkap juga sebagai Ninik Mamak yang di Nagari Bonjol. Daftar nama Datuak masing-masing suku di Nagari Bonjol dapat dilihat padaTabel 1.

Tabel 1. Nama Datuak perwakilan suku di Nagari Bonjol

Table1. Datuak tibal representativesin Nagan Banjd

\begin{tabular}{lll}
\hline No & \multicolumn{1}{c}{ Nama Suku (TribeName) } & \multicolumn{1}{c}{$\begin{array}{c}\text { Nama G elar/ D atuak } \\
\text { (Datuak nam) }\end{array}$} \\
\hline 1 & Piliang & Datuak Panghulu Kayo \\
\hline 2 & Patopang & D atuak Sangkutan \\
\hline 3 & Melayu & D atuak Panduko Sutan \\
\hline 4 & Chaniago & D atuak Panghulu Rajo \\
\hline 5 & Talao & Datuak Bandaro Putiah \\
\hline
\end{tabular}

Sumber (Sarce) : Profil Nagari Bonjol 2014 (Nagan Banjd Profile2014) 
Meskipun hanya sebuah Nagari/D esa, masyarakat Bonjol secara adat memiliki tanah ulayat yang sangat luas. Tanah ulayat adalah tanah yang secara hak de facto merupakan pola interaksi yang ditetapkan di luar lingkup hukum formal. Ini mencakup hak ulayat, seperangkat aturan dan peraturan masyarakat yang diwarisi dari nenek moyang dan diterima, ditafsirkan ulang, dan ditegakkan oleh masyarakat, dan yang mungkin diakui atau tidak oleh negara (Larson, 2012). Tanah ulayat di Nagari Bonjol mayoritas dimiliki oleh Suku Melayu. Suku lainnya memiliki tanah ulayat tetapi jumlahnya sedikit.

Tanah ulayat yang dikuasai Suku Melayu Bonjol tidak diketahui secara pasti luasnya. Hasil wawancara mendalam memperoleh informasi bahwa tanah ulayat yang diklaim Suku Melayu meliputi seluruh areal KPHP seluas 33.550 ha. D ulunya tanah ulayat Suku Melayu meliputi seluruh eks HPH Ragusa seluas 66.000 hayang saat ini telah menjadi KPHP (Inhutani dan DS) ditambah Hak Guna Usaha (HGU) PT. Sumatera Makmur Platation (SMP), PT. Andalas Wahana Berjaya (AWB), dan PT. Incasi Raya.

\section{B. Konflik Masyarakat Adat dengan Penguasa Lahan}

\section{Sejarah KPHP Model D harmasraya}

Unit VIII KPHP Model D hamasraya berada pada wilayah Kabupaten Dhamasraya Provinsi Sumatera Barat.Secara geografis KPHP terletak pada koordinat $01^{\circ} 03^{\prime} 30^{\prime \prime}$ LS- $01^{\circ} 22^{\prime} 00^{\prime \prime} L S$ dan $101^{\circ} 24^{\prime} 30^{\prime \prime}$ BT-101 ${ }^{\circ} 38^{\prime} 00^{\prime \prime} B T$. Secara administrasi KPHP terletak pada dua kecamatan, yaitu Kecamatan Pulau Punjung dan Kecamatan Koto Besar. Luas KPHP D harmasraya adalah 33.550 ha terdiri dari Hutan Produksi Tetap dan Hutan Produksi Terbatas (Dinas Kehutanan Kabupaten D harmasraya, 2014).

Wilayah Unit VIII KPHP Model Dhamasraya pembentukannya berdasarkan usul Bupati D hamasraya sesuai surat Nomor. 130/ 684/ BPT/ VIII-2013 tanggal 2 Agustus 2013 dan ditetapkan berdasarkan surat keputusan Menteri Kehutanan Republik Indonesia No. SK.695/ Menhut-II/ 2013 tanggal 21 Oktober 2013 tentang KPHP Model D hamasraya (UnitVIII) yang terletak di Kecamatan Koto Besar, Kabupaten Dhamasraya, Provinsi Sumatera Barat dengan luas $33.550 \mathrm{Ha}$. Secara wilayah K PHP Model D hamasraya terletak dibekas izin Inhutani dan DS(Dinas Kehutanan Kabupaten D harmasraya, 2014).

Ditilik dari sejarahnya, kawasan KPHP telah mengalami beberapa kali perubahan. Pada tahun 1972 kawasan hutan ini adalah sebuah Hak Pengusahaan Hutan (HPH) yang diberikan kepada PT. Ragusa seluas \pm 66.000 ha. Setelah berakhirnya $\mathrm{HPH}$ pada tahun 2002, sebagian area HPH menjadi hutan produksi yang dapat dikonversi dan telah diberikan HG Unya kepada tiga perusahaan perkebunan kelapa sawit, yakni PT. Incasi Raya, PT. SMP dan PT. AWB dengan luas 32.450 ha. Sisa HPH PT. Ragusa seluas 33.550 ha kemudian diberikan kepada tiga pemegang izin pemanfaaatan, yakni PT. Inhutani, D ara Silva, dan Bukit Raya Mudisa (BRM) sebagai Hutan Tanaman Industri. Pada tahun 2013 HTI yang dikuasai D S, Inhutani, dan BRM ditetapkan sebagai KPHP Model Dharmasraya (Dinas Kehutanan Kabupaten D harmasraya, 2014).

\section{Pluralisme Hukum Kepemilikan Hutan}

Pluralisme hukum atau legal prularalismmerupakan situasi di mana dua atau lebih sistem hukum berinteraksi dalam satu kehidupan sosial (Hooker, 1975). Berlakunya dua hukum atau lebih disuatu wilayah seringkali menimbulkan konflik. Konflik yang terjadi karena masing-masing pihak berusaha mencari pembenaran dari hukum yang diakui demi kepentingannya.

Pluralisme hukum juga terjadi di wilayah KPHP Model Dharmasraya. Meskipun secara hukum negara wilayah KPHP merupakan tanah yang dikuasai oleh negara, tetapi tidak berarti masyarakat lokal mengakui keberadaan hukum negara tentang pengaturan KPHP. Legl puralism kepemilikan hutan karena perbedaan penggunaaan hukum kepemilikan hutan. Pemerintah menggunakan hukum negara dengan menetapkan KPHP sebagai hutan negara, tetapi masyarakat menggunakan hukum adat yang diturunkan secara turun-temurun dengan batas alam seperti gunung, sungai bukit dan lainnya (Kadir \& al, 2013). Perbedaan penggunaaan hukum antara masyarakat dengan pemerintah yang kemudian menyebabkan konflik kehutanan.

Masyarakat adat Suku Melayu di Nagari Bonjol hanya mengakui keberadaan hukum adat dalam penguasaan hutan, dan tidak mengakui keberadaan hukum negara dalam pengaturan KPHP, sehingga masyarakat berhak mengambil dan menguasai 
hutan. Masyarakat adat bahkan menganggap negara tidak lebih berhak terhadap hutan, karena masyarakat adat telah tinggal di sekitar hutan sejak belum berdirinya negara ini, sehingga ketika negara mengambil hutan/tanah ulayat hal tersebut menimbulkan kemarahan di kalangan masyarakat adat di Nagari Bonjol.

Adanya leegl pluralismpengakuan hutan di areal KPHP antara negara dan masyarakat adat merupakan pemicu konflik agraria yang terjadi diwilayah ini, dan saat ini ketegangan antara masyarakat lokal dan negara masih terus terjadi dalam upaya mempertahankan penguasaan atas tanah. Hingga saat ini, sebagian besar areal KPHP telah dikuasai oleh masyarakat lokal dan diubah menjadi perkebunan karet dan kelapa sawit.

\section{Perebutan Lahan oleh Masyarakat}

Sejak ratusan tahun lalu, bekas HPH PT. Ragusa yang luasnya sekitar 66.000 ha secara adat merupakan tanah ulayat Suku Melayu di Nagari Bonjol. Akan tetapi masyarakat belum mengelola tanah ulayat ini karenajumlah penduduk yang masih sedikit dan kebutuhan tanah yang belum mendesak. Bahkan ketika PT. Ragusa masuk dan menguasai tanah Ulayat di Tahun 1972 belum ada perlawanan berarti dari masyarakat untuk merebut tanah ulayat yang dikuasai PT. Ragusa.

Perebutan lahan oleh masyarakat adat terjadi sekitar awal tahun 2000an, ketika izin HPH PT. Ragusa telah habis dan diberikan kepada beberapa perusahaan perkebunan kelapa sawit (AWB, SMP, dan Incasi Raya) dan perusahaan HTI (DS dan Inhutani), barulah masyarakat melakukan perlawanan untuk merebut tanah ulayat. Perebutan tanah ulayat oleh masyarakat terjadi karena jumlah penduduk masyarakat Bonjol yang semakin meningkat dan kebutuhan masyarakat terhadap lahan yang semakin tinggi, oleh karena itulah masyarakat beramai-ramai mengambil lahan ulayat yang dikuasai perusahaan. Menurut Hakim dan Sylviani (2014) hutan sebagai sumber pekerjaan dan pendapatan menjadi salah satu penyebab konflik di areal hutan.

Dibeberapa wilayah konflik seringkali terjadi karena masyarakat bermukim dihutan yang statusnya belum di endave(Harun dan D wiprabowo, 2014), tetapi di K PHP D harmasraya berbeda, yang terjadi masyarakat mengambil dan merebut hutan yang dikuasai pemegang izin. Tanah yang diambil merupakan hutan negara yang izinnya dikuasai D S dan Inhutani yang harusnya dijadikan hutan sekunder. Alasan masyarakat mengambil alih hutan adalah karena kedua perusahaan ini masuk mengambil alih lahan tanpa persetujuan penguasa ulayat dan Ninik Mamak Suku Melayu, sehingga secara adat kedua perusahaan tersebut tidak mempunyai hak untuk menguasai tanah. Berbeda dengan D S dan Inhutani, ketiga perusahaan HG U kelapa sawit (PT. SMP, AWB dan Incasi Raya) telah meminta izin kepada penguasa ulayat dan Ninik Mamak untuk mengelola tanah ulayat sehingga masyarakat tidak merebutnya.

Hasil wawancara diperoleh informasi bahwa syarat memperoleh izin mengambil hutan adalah melalui perjanjian antara perusahaan dengan pihak adat dengan pemberian sejumlah uang dari pihak perusahaan kepada pihak adat. Sayangnya, tidak semua masyarakat memperoleh keuntungan dari proses ini. Hanya orang tertentu yang memperoleh keuntungan dari proses pemberian izin, terutama yang memiliki kedekatan dengan penguasa adat. Alasan lain terjadinya perebutan hutan oleh masyarakat adalah terjadi kekosongan pengelolaan hutan oleh D S dan Inhutani sehingga masyarakat masuk dan mengambil alih hutan. Beberapa kasus konflik kehutanan di Indonesia terjadi akibat kekosongan pengelolaan hutan oleh pemegang izin (Harun dan D wiprabowo, 2014).

Proses pengambil alihan lahan perusahaan oleh masyarakat diawali dengan penebangan pohon jabon (Anthocephaluscadamba) milik D S dan meranti (Shorea leprosula) milik Inhutani. Setelah penebangan jabon (Anthocephalus cadanba) dan meranti (Shorea leprosula), kemudian masyarakat membuka hutan dan menanaminya dengan tanaman karet dan kelapa sawit. Setelah masyarakat menanami lahan dengan karet dan kelapa sawit, berarti lahan tersebut telah menjadi milik masyarakat dan apabila perusahaan ingin mengambil lahan yang telah ditanami masyarakat, pihak perusahaan harus membayar sejumlah uang kepada masyarakat sebagai syarat mengambil lahan. Apabila perusahaan tidak bersedia membayar berarti perusahaan harus merelakan tanah tersebut menjadi hak milik masyarakat.

\section{Alih Fungsi Hutan menjadi Perkebunan}

Hutan produksi di KPHP seluas 33.500 ha secara bertahap telah menjadi perkebunan kelapa sawit dan karet. Perubahan hutan menjadi kebun kelapa sawit dan karet terjadi sejak tahun awal 


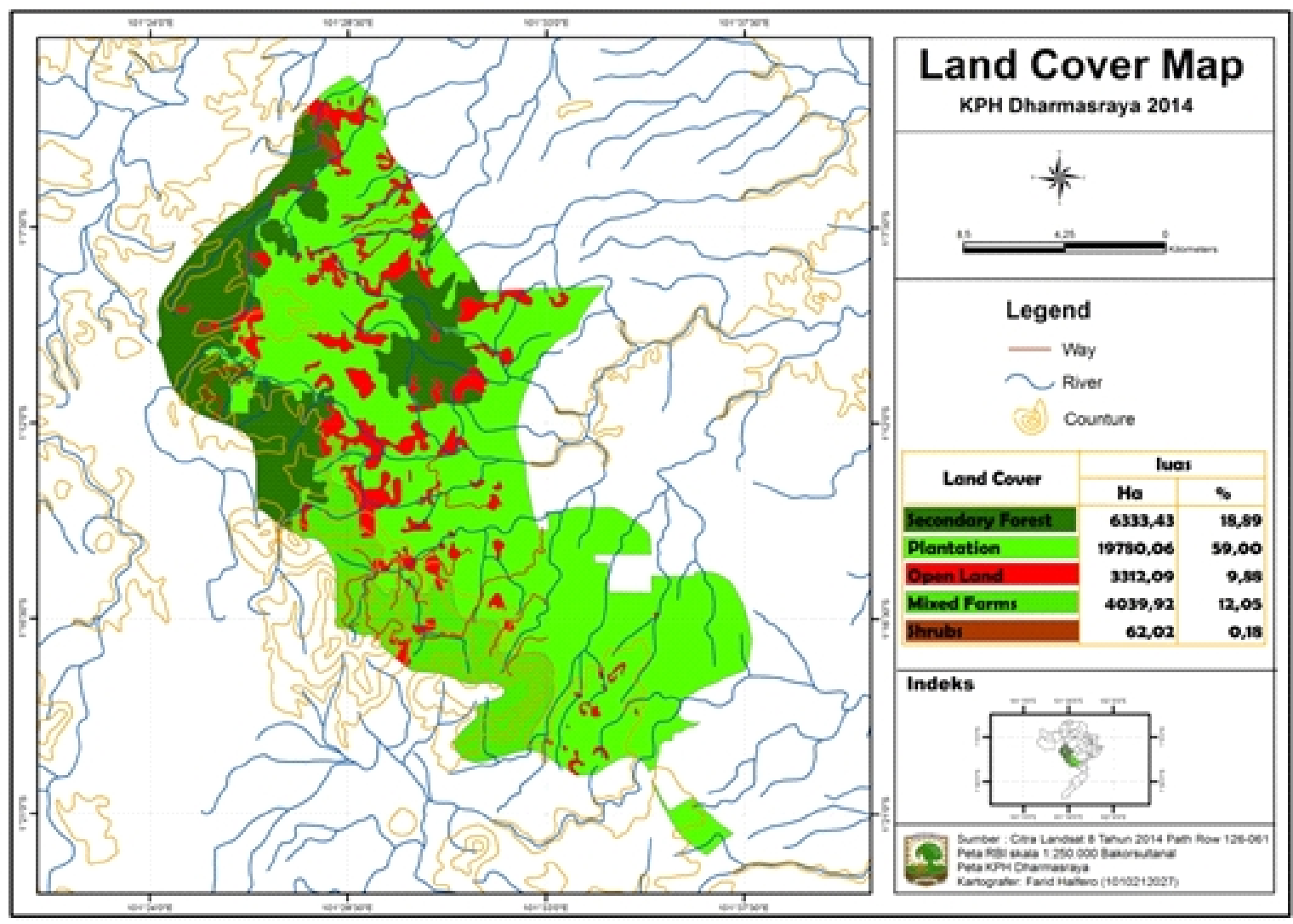

Sumber (Saurce): Yonariza (2015)

Gambar 2. Tutupan hutan di KPHP D harmasraya tahun 2013.

Figure2. Forest cover in FMU Dharmasraya in 2013.

tahun 2000 ketika masyarakat berhasil menduduki hutan DS dan Inhutani. Setelah menguasai hutan, masyarakat langsung menebang dan menanaminya dengan tanaman perkebunan. Perubahan hutan menjadi perkebunan juga dipengaruhi oleh banyaknya pihak luar Nagari Bonjol yang membeli tanah ulayat kemudian menanaminya dengan kelapa sawit dan karet sebagai bentuk investasi.

Tutupan hutan sekunder di areal KPHP Model D harmasraya pada tahun 2014 ditampilkan pada Gambar2.

Seperti yang ditampilkan pada Gambar 2, pada tahun 2014 tutupan hutan di K PHP tersisa 6.333,43 haatau 18,89\%, dan sebanyak 19.780,06 hektar atau $59,00 \%$ telah menjadi perkebunan. Padahal pada tahun 2000 sekitar 86,35\% area KPHP masih berupa hutan. Perkebunan rakyat di areal KPHP didominasi oleh kelapa sawit dan karet yang dimiliki oleh masyarakat Nagari Bonjol serta masyarakat luar Nagari Bonjol yang telah membeli tanah ulayat.

\section{Pelepasan Tanah Ulayat}

Keberhasilan masyarakat lokal merebut hutan dari perusahaan telah menyebabkan terjadinya alih fungsi hutan di areal KPHP. Akan tetapi keberhasilan masyarakat lokal merebut hutan tidak menjamin seluruh masyarakat Bonjol dapat menikmati tanah ulayat, yang terjadi kemudian adalah adanya penjualan tanah ulayat kepada masyarakat luar Nagari Bonjol dengan skala yang besar. Kegiatan jual beli tanah ulayat terjadi karena tanah ulayat dikuasai oleh "Datuak Penguasa Ulayat", sehingga sang Datuak berhak menjual tanah ulayat kepada siapapun termasuk masyarakat non Suku Melayu dan masyarakat diluar Nagari Bonjol. Salah satu bagian penting dari kegiatan jual beli tanah ulayat adalah terbitnya "alas hak" dari Datuak Penguasa Ulayat sebagai bukti sah kepemilikan tanah.

1. Sistem "Alas Hak"

Kegiatan jual beli tanah ulayat di Nagari Bonjol 
memiliki tata cara dan mekanisme yang khas jika dibandingkan dengan jual beli pada umumnya. Jika jual beli tanah pada umumnya menggunakan sertifikat sebagai bukti sah kepemilikan, maka di Nagari Bonjol jual beli tanah tidak menggunakan sertifikat, tetapi yang digunakan adalah "alas hak" dari pemilik ulayat.

Alas hak adalah bukti dasar jual beli antara pemilik ulayat dan pembeli. Bentuk alashak adalah surat perjanjian jual beli pemilik ulayat dengan pembeli yang diketahui oleh perangkat adat dan nagari. Kegiatan jual beli tanah ulayat harus mendapat persetujuan dari dari Ninik Mamak suku pemilik ulayat dan Ketua Kerapatan Adat Nagari (KAN), serta diketahui oleh Wali Nagari. Namun, kenyataan dilapangan proses jual beli dan proses pengeluaran alas hak cukup disetujui oleh D atuak penguasa ulayat tanpa persetujuan Ninik Mamak dan Ketua KAN. Sedankan Kepala Nagari hanya sebagai pihak yang mengetahui kegiatan jual beli tanah ulayat dan pembuatan bukti alashak.

Hasil wawancara dengan beberapa tokoh kunci dan masyarakat, alashakmerupakan bukti yang kuat dan sah dalam kepemilikan tanah ulayat di Nagari Bonjol. Meskipun tanah yang dibeli adalah tanah ulayat yang masih di areal hutan negara, mereka tidak khawatir dan takut apabila dikemudian hari terjadi masalah akibat proses jual beli tanah tersebut. Hal ini terjadi karena tingginya pengakuan masyarakat terhadap hukum adat masih begitu kuat mengamalkan adat-istiadat dan aturan-aturan yang diwariskan dalam penguasaan tanah ulayat. Ketika disinggung tentang keberadaan hutan negara yang secara hukum negara tidak boleh dibuka, masyarakat mengaku mereka lebih mengakui keberadaan hukum adat dibandingkan hukum negara.

\section{ProsesJual BeliTanah Ulayat}

Pada dasarnya tanah ulayat di Nagari Bonjol merupakan tanah ulayat milik Suku Melayu yang hanya boleh dimanfaatkan oleh masyarakat Suku Melayu. Tanah ulayat diperbolehkan dijual dengan syarat tertentu sesuai dengan aturan adat dan persetujuan Ninik mamak. Tetapi yang terjadi di Nagari Bonjol, tanah ulayat oleh penguasanya perjual-belikan kepada siapapun, tidak hanya masyarakat Suku Melayu dan suku lainnya di Nagari Bonjol, tetapi juga masyarakat diluar Nagari Bonjol bahkan masyarakat seluruh Sumatera Barat diperbolehkan membeli tanah ulayat.

Saat ini fungsi tanah ulayat di Nagari Bonjol tidak hanya diberikan kepada saudara satu suku yang membutuhkan tanah sebagai sumber penghidupan, tetapi dijual kepada siapapun yang memiliki uang. Yang lebih mencengangkan adalah kegiatan jual beli tanah ulayat ini tidak dibatasi luasnya oleh pemilik ulayat, siapapun boleh membeli lahan seluas 50, 100, 200, 500 bahkan 1.000 ha asalkan mampu membelinya.

Hasil diskusi dengan masyarakat dan tokoh adat diperoleh informasi tentang kisaran harga tanah ulayat. Kisaran harga tanah ulayat di Nagari Bonjol disesuaikan dengan jauh dekat lokasi dan kondisi lahan. Untuk melihat klasifikasi harga jual tanah ulayat di NagariBonjol dapat dilihat di Tabel 2.

Tabel 2. Harga Tanah ulayat suku melayu berdasarkan kriteria lokasi dan kemiringan lahan.

Tade2. Commual landprice of mayu tribebaseon thelocation and sqpe

\begin{tabular}{|c|c|c|}
\hline $\begin{array}{l}\text { Tipe lahan } \\
\text { (Landtype) }\end{array}$ & $\begin{array}{l}\text { Kriteria lahan } \\
\text { (Land diteria) }\end{array}$ & $\begin{array}{l}\text { Harga/ ha (Rupiah) } \\
\text { (Pricd ha(IDR) }\end{array}$ \\
\hline Tipe A & $\begin{array}{l}\text { 1. Lokasi dekat dengan perkampungan } \\
\text { 2. Tanah landai/ datar }\end{array}$ & $>10.000 .000$ \\
\hline Tipe B & $\begin{array}{l}\text { 1. Lokasi dekat dengan perkampungan } \\
\text { 2. Tanah berbukit/ kemiringan lahan tinggi }\end{array}$ & $7.000 .000-10.000 .000$ \\
\hline Tipe C & $\begin{array}{l}\text { 1. Lokasi jauh dari perkampungan } \\
\text { 2. Kemiringan lahan rendah }\end{array}$ & $4.000 .000-7.000 .000$ \\
\hline Tipe D & $\begin{array}{l}\text { 1. Lokasi jauh dari perkampungan } \\
\text { 2. Kemiringan lahan tinggi }\end{array}$ & $2.000 .000-4.000 .000$ \\
\hline
\end{tabular}

Sumber (Sarce): Mutolib \&al. (2015) 


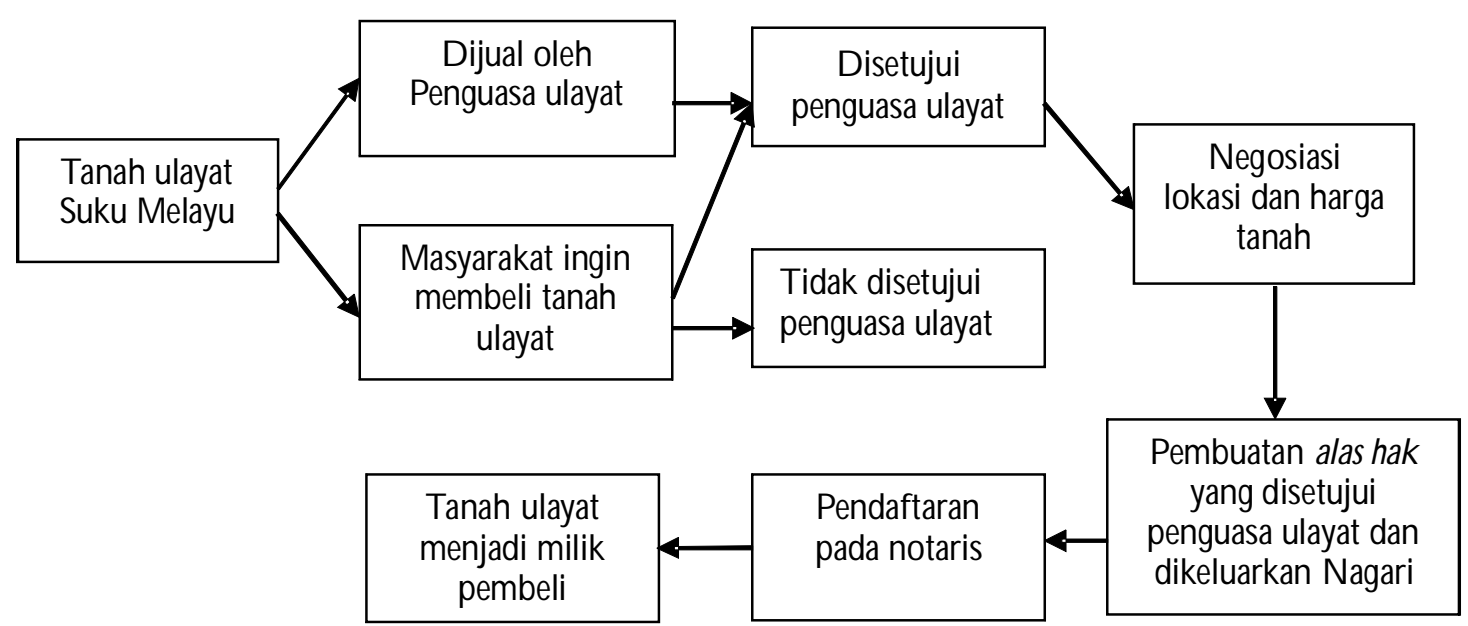

Sumber (Sarre): D ata Primer (Primary data), 2015

Gambar 3. Proses jual beli tanah ulayat di Nagari Bonjol.

Figure3. Buyingandsdlingprocess of commmal landinBanjd.

Akibat kegiatan jual beli tanah ulayat dan tidak adanya kontrol dari penguasa ulayat, saat ini tanah ulayat di Nagari Bonjol menjadi semakin sedikit jumlahnya, masyarakat yang ingin bertani dan berkebun harus menempuh jarak 2-3 jam menggunakan motor/ mobil. Jual beli tanah ulayat tidak hanya melibatkan masyarakat, tetapi pejabat dari tingkat kabupaten dan provinsi. Proses jual beli tanah ulayat di Nagari Bonjol dijelaskan pada Gambar 3.

3. Ketimpangan Penguasaan Tanah antara MasyarakatBonjol dan Luar Bonjol

Masyarakat Nagari Bonjol telah berhasil merebut tanah ulayat mereka dari perusahaan dan negara, tetapi keberhasilan merebut lahan tidak membuat semua masyarakat di Nagari Bonjol mempunyai lahan yang luas. Hal ini dikarenakan tanah ulayat di K PHP hanya dimiliki Suku Melayu saja, sehingga masyarakat dari suku lain yang ingin membuka lahan harus meminta izin dengan Datuak Penguasa Ulayat dengan luasan yang terbatas. Masyarakat Suku Melayu diperbolehkan membuka lahan dalam jumlah tidak terbatas tetapi keterbatasan modal menjadikan masyarakat hanya mampu membukalahan dalam jumlah yang sedikit.

Menurut penelitian Mutolib \& al. (2015), penguasaan lahan per rumah tangga di Nagari Bonjol (baik Suku Melayu dan non Melayu) cenderung sempit dibandingkan dengan luasnya tanah ulayat yang dikuasai masyarakat dari luar Nagari Bonjol yang berinvestasi dengan membeli tanah ulayat Suku Melayu. Luasan rata-rata lahan yang dikuasai masyarakat Nagari Bonjol dapat ditampilkan pada Tabel 3.

Tabel 3. Luas lahan rumah tangga penelitian.

\section{Table3. Sizeof small hdder landarea.}

\begin{tabular}{cccc}
\hline No & $\begin{array}{c}\text { Luas lahan (Ha) } \\
\text { (Landara) }\end{array}$ & $\begin{array}{c}\text { Jumlah } \\
\text { (Numba) }\end{array}$ & $\begin{array}{c}\text { Persentase (\%) } \\
\text { (Perentag) }\end{array}$ \\
\hline 1 & $0-2$ & 22 & 53,66 \\
\hline 2 & $>2-5$ & 11 & 26,82 \\
\hline 3 & $>5-10$ & 3 & 7,32 \\
\hline 4 & $>10-20$ & 3 & 7,32 \\
\hline 5 & $>20$ & 2 & 4,88 \\
\hline & Jumlah (Tdal) & 41 & 100,00 \\
\hline
\end{tabular}

Sumber (Sarce): Mutolib \&al. (2015) 
Tabel 4. Luasan tanah ulayat yang dikuasai masyarakat luar Bonjol

Table4. Thearea of commmal land onnedbyautsideof Bonjd

\begin{tabular}{llcc}
\hline No & \multicolumn{1}{c}{$\begin{array}{c}\text { Nama (Nama disamarkan) } \\
\text { (Nameof owner(indisguise) }\end{array}$} & $\begin{array}{c}\text { Luas } \\
\text { (Area) }\end{array}$ & $\begin{array}{c}\text { Domisili } \\
\text { (Origin) }\end{array}$ \\
\hline 1 & Pemilik 1 & 140 ha & Padang \\
\hline 2 & Pemilik 2 & 25 ha & Padang \\
\hline 3 & Pemilik 3 & 50 ha & Padang \\
\hline 3 & Pemilik 4 & 25 ha & Pulau Punjung D harmasraya \\
\hline 4 & Pemilik 5 & 20 ha & Padang \\
\hline 5 & Pemilik 6 & $>100$ ha & Solok Selatan \\
\hline 6 & Pemilik 7 & $>500$ ha & Sungai Rumbai D harmasraya \\
\hline 7 & Beberapa warga Nagari Bonjol & $>100$ ha & Nagari Bonjol \\
\hline
\end{tabular}

Sumber (Sarre): Mutolib eal.(2015)

Tabel 3 memperlihatkan bahwa sebagian besar masyarakat Bonjol memiliki luas tanah 0-2 ha. Tetapi ada beberapa warga yang luas tanahnya mencapai 10-20 ha, bahkan beberapa warga mempunyai luas lahan diatas 20 ha. Luasan tanah masyarakat Bonjol sangat berbeda dibandingkan luasan tanah yang dikuasai masyarakat luar Bonjol (Tabel 4). Banyak masyarakat luar Bonjol yang membeli tanah seluas puluhan hingga ratusan hektar. G ambaran luasan lahan ulayat yang dikuasai masyarakat luarNagari Bonjol ditampilkan pada Tabel4.

Melalui Tabel 3 dan 4 dapat diketahui bahwa terjadi gap yang begitu besar antara tanah yang dikuasai oleh masyarakat Bonjol dan masyarakat luar Bonjol. Perbedaan yang begitu besar dikarenakan banyak masyarakat asli Bonjol yang tidak mempunyai biaya untuk membuka perkebunan, serta tidak memiliki wewenang dalam pemerintahan adat, sedangkan masyarakat luar Bonjol memiliki lahan yang luas karena mereka didukung modal yang cukup untuk membeli kebun Mutolib \&al. (2015). Meskipun begitu, banyak juga masyarakat Bonjol yang mempunyai kebun seluas puluhan hingga ratusan hektar, orang-orang tersebut biasanya terdiri dari pimpinan adat, pimpinan nagari, atau tokoh adat yang memiliki kekuatan dan wewenang dalam masyarakat. Masyarakat luar Nagari Bonjol yang membeli tanah ulayat didominasi oleh para pejabat baik dari tingkat kabupaten hingga provinsi. Umumnya mereka membeli tanah ulayat kemudian diatanami dengan kelapa sawit dan karet sebagai investasi jangka panjang (Mutolib \&al., 2015).

\section{D.Absennya Pemenintah dan Pemegang Izin dalam Perlindungan H utan}

Keberanian masyarakat merebut dan membuka hutan, selain dipengaruhi oleh pengakuan hukum adat terhadap tanah ulayat yang lebih tinggi dibandingkan hukum negara, juga disebabkan absennya aparat negara atau pemegang izin untuk mencegah pembukaan hutan oleh masyarakat. Akibatnya, masyarakat menjadi semakin berani membuka hutan yang saat ini menjadi areal KPHP. Wawancara dengan rumah tangga di Nagari Bonjol membuktikan bahwa peran pemerintah dan pemegang izin dalam pengelolaan hutan sangat rendah. Bahkan pemerintah dan pemegang izin membiarkan hutan begitu saja, sehingga memicu masyarakat untuk masuk dan menguasai hutan. Hasil wawancara dengan masyarakat terkait pengawasan hutan oleh pihak terkait ditampilkan padaTabel 5 .

Jawaban pada Tabel 5 menggambarkan bahwa $100 \%$ responden mengaku pemerintah absen dalam pengawasan dan perlindungan hutan. $\mathrm{Hal}$ tersebut menggambarkan bahwa masyarakat tidak pernah merasakan keberadaan pemerintah dalam pengelolaan hutan seperti pengawasan atau patroli pengamanan hutan, penangkapan pelaku perambahan hutan, pemberian sanksi bagi perambah hutan maupun melakukan kegiatan penyuluhan tentang pentingnya menjaga hutan. D ari keseluruhan responden, hanya 4 orang atau 9,75\% yang khawatir membuka hutan, tetapi sebanyak 90,25\% tidak khawatir membuka lahan di areal hutan. Keberanian masyarakat disebabkan 
Tabel 5. Kegiatan pengawasan hutan oleh pemerintah.

Table5. Forest monitoningadivities byguement.

\begin{tabular}{lllc}
\hline No & \multicolumn{1}{c}{ Pertanyaan (Question) } & Ya (Yes) & Tidak (No) \\
\hline 1 & Adakah patroli untuk mengamankan kehutanan dari dinas terkait? & $0,00 \%$ & $100,00 \%$ \\
2 & $\begin{array}{l}\text { Adakah masyarakat yang ditangkap akibat membuka kebun didalam } \\
\text { hutan produksi? }\end{array}$ & $0,00 \%$ & $100,00 \%$ \\
3 & $\begin{array}{l}\text { Adakah masyarakat yang terkena sanksi akibat membuka kebun } \\
\text { didalam hutan? }\end{array}$ & $0,00 \%$ & $100,00 \%$ \\
4 & $\begin{array}{l}\text { Adakah kegiatan penyuluhan tentang pentingnya menjaga } \\
\text { hutan/ nimbo }\end{array}$ & $0,00 \%$ & $100,00 \%$ \\
5 & $\begin{array}{l}\text { Adakah kegiatan penyuluhan tentang tanaman perkebunan } \\
\text { rekomendasi yang harus ditanam di hutan/ imbo? }\end{array}$ & $0,00 \%$ & $100,00 \%$ \\
6 & Adakah rasa kekhawatiran karena membuka hutan? & $9,75 \%$ & $90,25 \%$
\end{tabular}

Sumber(Saurce): D ata Primer (2015)

kuatnya pengakuan terhadap hukum adat dibandingkan hukum negara.

Critchley \& al. (2004) menyebutkan bahwa pengawasan merupakan salah satu kunci utama dalam keberhasilan manajemen lingkungan dengan masyarakat. Subarudi (2008) menyebutkan bahwa pengawasan dan evaluasi merupakan salah satu kunci dalam tata kelola kehutanan yang baik. .

\section{KESIMPULAN DAN SARAN}

\section{A. Kesimpulan}

Konflik agraria di wilayah KPHP terjadi karena saling klaim antara masyarakat dan pemerintah terhadap kepemilikan hutan. Masyarakat mengklaim hutan negara yang izinnya diberikan kepada perusahaan HPH dan HTI sebagai tanah ulayat masyarakat adat Nagari Bonjol yang telah ditempati sejak ratusan tahun. Akibat konflik agraria ini, masyarakat adat Suku Melayu merebut hutan dari perusahaan dan memperjualbelikan tanah ulayat secara bebas. Maraknya jual beli tanah ulayat di Nagari Bonjol dikarenakan Penguasa Ulayat memperjualbelikan tanah ulayat tanpa mempertimbangkan kebutuhan jangka panjang. Selain itu, tidak adanya kontrol dari masyarakat menyebabkan penguasa ulayat semakin bebas dalam menjual tanah ulayat. Bukti sah dan diakuinya jual beli tanah ulayat adalah adanya alas hak yang dikeluarkan oleh pihak Nagari Bonjol yang ditandatangani (disetujui) penguasa ulayat.

\section{B. Saran}

Untuk mewujudkan pengelolaan KPHP yang baik perlu memperjelas hak dan batas tanah ulayat yang dikuasai oleh masyarakat Suku Melayu dan hutan yang dikuasai perusahaan HTI. Karena konflik agraria yang terjadi di KPHP karena ketidakjelasan kepemilikan hutan antara pihak masyarakat dan perusahaan pemegang izin.

Keberadaan masyarakat adat Suku Melayu dan tanah ulayatnya juga perlu menjadi perhatian penting dalam pengelolaan KPHP. Pemerintah Kabupaten Dharmasraya terutama dinas terkait perlu melibatkan masyarakat pengelolaan hutan di KPHP. Keterlibatan masyarakat dalam pengelolaan diyakini akan mampu mengurangi konflik yang terjadi akibat persepsi masyarakat yang menganggap negara telah merebut tanah ulayatnya.

Selain pelibatan masyarakat dalam pengelolaan hutan, perlunya implementasi program yang tidak hanya bertujuan memperbaiki kondisi hutan yang telah terdegradasi di KPHP, tetapi mempertimbangkan kepentingan masyarakat sekitar yang menggantungkan hidupnya dari hutan. Salah satu alternatif yang bisa ditempuh adalah dengan melaksanakan program Hutan Kemasyarakatan, atau Hutan Desa/ Nagari di KPHP untuk mengakomodasi kepentingan masyarakat yang menggantungkan hidupnya dari pemanfaatan hutan. 


\section{UCAPAN TERIMA KASIH}

Penulis mengucapkan terima kasih kepada Kementerian Riset, Teknologi dan Pendidikan Tinggi yang telah memberi pendanaan melalui hibah penelitian Program Menuju Doktor Sarjana Unggul (PMD SU) tahun anggaran 2014-2015.

\section{DAFTAR PUSTAKA}

Afrizal. (2015). Metode penditian kualitatif: sebuah upayamendukungpenggunaan penditiankualitatif dalam berbagai disiplin ilmu Jakarta: Raja Grafindo Persada.

Astuti, P. (2011). Kdkerasan dalam konflik agrania: Kexagalan negara dalam meniptakan keadilan di bidang patamahanDiunduh 16 Mei 2015 dari http:/ / ejournal.undip.ac.id/ index.php/ foru m/ article/ download/ 3158/ 2834.

Badan Pusat Statistik Kabupaten Dharmasraya. (2014). Kabupaten Dhamasraya DalamAngka 2014. Pulau Punjung: BPS Kabupaten Dharmasraya.

Benjamin, C. E. (2008). Legal pluralism and decentralization: natural resourcemanagement in Mali. World Deudqument,36,2255-2276.

Bungin, B. (2010). Penditiankualitatif: Kommikasi, dkonom, kebjakanpubik, danilmusosial lainnya. Jakarta: KencanaPrenada Media G rup.

Bogdan, R. C. \& Biklen, S. K. (1992). Qualitative rescarchforeducation: Anintroductiontothearyand mthook Boston: Allyn \& Bacon.

Creswell, J. W. (1994).Research design :Qualitativeand quantitative approades California: SAGE Publications, Inc.

Critchley, C. N. R., Burke, M. J. W.,\& Stevens, D. P.(2004). Conservation of lowland seminatural grasslands in the UK: a review of botanical monitoring results from agrienvironment schemes. Biological Conservation,115(2), 263-278.

Colchester, M. \& Chao, S. (2011). Ekspansi kdapa sanit di Asia Tenggara: Sebuah tinjauan
Diunduh 23 April 2015 dari http:/ / www.forestpeoples.org/ .

D inas Kehutanan Kabupaten Dharmasraya. (2014). Rencana pengddaan hutan jangka panjang kesaturan pemangku hutan produks (RPHJP KPHP) modd Dhamasraya 20152024. Pulau Punjung: Dinas Kehutanan Kabupaten D harmasraya.

Djari. (2009). Pengembangan sistem penyuluhan perikanan era desentralisasi d Indonesa. Bogor: Institut Pertanian Bogor.

Faisal, S. (1990). Penditiankualitatif: Dasar-dasar dan aplikasi. Malang: Yayasan Asah Asih Asuh (YA3 Malang).

G riffiths, J. (1986).'What is legal pluralism? Jaumal of Legl Pluralism\&Unofficial Law24, 1-56.

Hakim, I. \& Sylviani. (2014). Analisis tenurial dalam pengembangan kesatuan pengelolaan hutan (KPH): studi kasus KPH Gedong Wani, Provinsi Lampung. Jumal Penditian Sosial danEkonomi Kehutanan,11(4), 309-322.

Harun, M.K. \& D wiprabowo, H. (2014). Model resolusi konflik lahan di kesatuan pemangkuan hutan produksi model Banjar. Jumal Penditian Sosial danEkonomi Khutanan, 11(4), 265-280.

Hooker, M. B.(1975). Legl puralism Introductionto colonial andneocdonial law London: Oxford University Press.

Kadir W. A., Nurhaedah, M. \& Purwanti, R. (2013). Konflik pada kawasan taman nasional Bantimurung Bulusaraung Provinsi Sulawesi Selatan dan upaya penyelesaiannya. Jumal Penditian Sosial dan Ekonomi Kdutanan, 10(3), $186-198$.

Indrawardi. (2008). Perananninik mamak (datuk) d Minangkabau dalam MendukungKetahanan Daerah Studi Kasus di Nagai Pakan Sinayan KecamatanBanuhampu-Kabupaten AgamSumatera Barat. (Thesis Pascasarjana). Universitas Indonesia. Depok.

Larson, A.M. (2012). Tenurenightsandaccesstoforests A trainingmanual forrearch Bogor:CIFOR. 
Mantiri, M. M. (2007). Analisis konflik agania di pedksaan (suatu studi di desa Lemoh Barat Kecamatan Tombanin). Diunduh 16 Mei 2015 dari http:// download.portalgaruda.org/ article.php?article $=106894 \& v a l=1037$.

Miles, M. B. \& A. M. Huberman. (1992). Qualitative data analysis:A sarcebook of new mothook Diterjemahkan oleh Rohidi, Tjetjep Rohendi. Jakarta: Universitas Indonesia Press.

Moleong, L. J. (1996). Metode penditian kualitatif Bandung: Remaja Rosdakarya.

Mutolib, A., Yonariza., Mahdi, \& Ismono, $\mathrm{H}$. (2015). Local resistance to land grabbing in Dharmasraya District, West Sumatra Province. Paper presenteebt The Intemational Acadaric Conferene Land Grabling Pespeetives fromEast and Sathest Asia 2015, June 5-6, 2015. Chiang Mai University, Thailand.

Onibon, A., D abiré, B., dan Ferroukhi, L. (1999). Local practice and decentralization and devolution of natural resources management in West Africa. Unasyka,50, 23-27.

Sugiyono. (2013). Medodpenditiankombinas (mixed mthoods).Bandung: Alfabeta.

Subarudi. (2008). Tata kelola kehutanan yang baik: Sebuah pembelajaran dari kabupaten Sragen. Jumal Analisis Kdajakan Kdutanan, 5(3), 179-192.

Von Benda-Beckmann, D. (1981). Forum shopping and shopping forums. Jamal dLegal Pluralism19, 117-159.

Yonariza.2015.Overlapping oil palm plantation and forest area: case of production forest management unit (FMU) of D harmasraya District, West Sumatra.Paper presented at The International Seminar on Tropical Natural Resources 2015,June 10-12, 2015. MataramLombok, Indonesia. 